\title{
Guanine-Plus-Cytosine Compositions of and Deoxyribonucleic Acid Hybridization Comparisons between Mycoplasma hyopneumoniae and Mycoplasma flocculare
}

\author{
GERALD W. STEMKE, ${ }^{1 *}$ DEBRA J. MCINTYRE, ${ }^{1}$ KENNETH L. ROY, ${ }^{1}$ MARGARET E. STEMLER,${ }^{2}$ AND \\ JANET A. ROBERTSON ${ }^{2}$ \\ Department of Microbiology ${ }^{1}$ and Department of Medical Microbiology, ${ }^{2}$ University of Alberta, Edmonton, Alberta, \\ Canada T6G $2 E 9$
}

\begin{abstract}
Among the mycoplasmal species commonly isolated from porcine lungs are Mycoplasma hyopneumoniae and Mycoplasma flocculare. The former organism is a proven agent of enzootic porcine pneumonia, whereas the latter organism is of little or no pathogenicity. These mycoplasmas show considerable antigenic cross-reactivity. The deoxyribonucleic acids of $M$. hyopneumoniae strain 11 and $M$. flocculare strain $\mathrm{Ms42}^{\mathrm{T}}(\mathrm{T}=$ type strain) each had a guanine-plus-cytosine content of $33 \mathrm{~mol} \%$. We also determined the extent of deoxyribonucleic acid sequence homology as reflected in deoxyribonucleic acid-deoxyribonucleic acid hybridization values. Approximately $10 \%$ heterologous hybridization was observed. Thus, our data support the previous classification of these organisms as separate species within the genus Mycoplasma.
\end{abstract}

Among the several mycoplasmas commonly isolated from porcine pneumonic lungs are Mycoplasma hyopneumoniae and Mycoplasma flocculare. Studies have implicated $M$. hyopneumoniae as an etiological agent of porcine mycoplasmal pneumonia (enzootic porcine pneumonia) (16). No convincing evidence implicating $M$. flocculare in porcine mycoplasmal pneumonia has been presented. The taxonomic relationship between $M$. hyopneumoniae (Mycoplasma suipneumoniae) and $M$. flocculare has been described previously (15); there are few biological or cultural differences between these two mycoplasmas, although distinction can be made on the basis of serological properties, growth inhibition, or plate fluorescent antibody tests (15). However, $M$. flocculare cross-reacts serologically in other tests with $M$. hyopneumoniae; multiple peptides of $M$. flocculare react with antiserum to $M$. hyopneumoniae in two-dimensional immunoelectrophoresis (13), whereas whole organism-based enzyme-linked immunosorbent assays show great cross-reactivity (3). Since antibody to $M$. flocculare, a common swine isolate, is also detected with $M$. hyopneumoniae as antigen in a variety of serological tests, antigenic cross-reactivity has proven to be a major hindrance to the serodiagnosis of porcine mycoplasmal pneumonia. In an attempt to learn more of the genetic relationship between these mycoplasmas we characterized their deoxyribonucleic acids (DNAs).

$M$. hyopneumoniae strain 11 (= ATCC 25095) and $M$. flocculare $\mathrm{Ms} 42^{\mathrm{T}}\left(=\mathrm{ATCC} 27716^{\mathrm{T}}\right)(\mathrm{T}=$ type strain) were cultured in Friis medium (5) and harvested in the log phase of growth, as determined by the adenosine triphosphate level, using a luciferin-luciferase luminometry method (J. A. Robertson, M. E. Stemler, and G. W. Stemke, Abstr. 5th Int. Cong. Int. Org. Mycoplasmology, p. 137, 1984) to monitor growth.

$M$. hyopneumoniae strain 11 was originally designated the type strain (8). Because the current strain 11 in the American Type Culture Collection may not be identical to that original strain, strain $\mathbf{J}$, which is serologically and biochemically indistinguishable from strain $11(13,15)$, was designated the type strain of $M$. hyopneumoniae (15). Mycoplasma hominis

\footnotetext{
* Corresponding author.
}

ATCC 14027 and Mycoplasma pneumoniae ATCC 15531 were grown in bromthymol blue broth (14) and SP4 broth (19), respectively. The cells were collected by centrifugation and then lysed by adding $2 \%$ (wt/vol) Sarkosyl in $10 \mathrm{mM}$ ethylenediaminetetraacetate-10 $\mathrm{mM}$ tris(hydroxymethyl) aminomethane $(\mathrm{pH})-10 \mathrm{mM}$ sodium chloride; this was followed by incubation at $50^{\circ} \mathrm{C}$ for $60 \mathrm{~min}$. Protein was digested with proteinase $\mathrm{K}(0.2 \mathrm{mg} / \mathrm{ml})$ for $16 \mathrm{~h}$ at $37^{\circ} \mathrm{C}$. DNA was purified by isodensity ultracentrifugation in cesium chloride-ethidium bromide. The red band was removed and extracted with butanol to remove the dye. The DNA was then precipitated in the cold with $70 \%$ ethanol and dissolved in a minimal volume of tris(hydroxymethyl)aminomethaneethylenediaminetetraacetate. The DNA samples purified in this way had proper ratios or absorbance at $260 \mathrm{~nm}$ to absorbance at $280 \mathrm{~nm}$ (approximately 2) and were readily digested by appropriate restriction nucleases; these are indications of relative purity.

Guanine-plus-cytosine $(G+C)$ contents were determined by melting point and density methods. The density method of DeLey (1) as modified by Szybalski and Szybalski (18) was used with Pseudomonas aeruginosa DNA as the standard. The method of Owen et al. (11) was followed for melting point determinations by using a Beckman model DU-8 spectrophotometer equipped with programmable heating and absorbance recording equipment; calf thymus DNA was used as the standard. The values of the melting point determinations were corrected for the concentration of $\mathrm{Na}^{+}$ in the buffer. The results of this experiment are shown in Table 1. Both porcine mycoplasma DNAs had a melting point in $0.5 \times \mathrm{SSC}(1 \times \mathrm{SSC}$ is $0.15 \mathrm{M} \mathrm{NaCl}$ plus $0.015 \mathrm{M}$ sodium citrate) of $78^{\circ} \mathrm{C}$ or, within experimental precision, a $\mathrm{G}+\mathrm{C}$ content of $33 \mathrm{~mol} \%$. Similar or identical $\mathrm{G}+\mathrm{C}$ contents occur in a number of Mycoplasma species and are, therefore, not an indication of a close genetic relationship. In fact, most Mycoplasma species have $\mathrm{G}+\mathrm{C}$ contents that range between 24 and $40 \mathrm{~mol} \%$ (4). The consistent values (42 to 43 mol\%) obtained for $M$. pneumoniae by the two methods used in this study are higher than those reported elsewhere (10); in fact, we used the same strain for our determinations that was used in the previous study. If our values are 
TABLE 1. G + C contents of mycoplasmal DNAs

\begin{tabular}{lcc}
\hline \multirow{2}{*}{ DNA source } & \multicolumn{2}{c}{$\mathrm{G}+\mathrm{C}$ content (mol\%) as determined by the: } \\
\cline { 2 - 3 } & Melting point method & Specific density method \\
\hline$M$. hyopneumoniae & 33 & $32-33$ \\
$M$. flocculare & 33 & 33 \\
$M$. pneumoniae & $42-43$ & 43 \\
Calf thymus & 42.4 & $\mathrm{ND}^{a}$ \\
$P$. aeruginosa & $\mathrm{ND}$ & 67 \\
\hline
\end{tabular}

${ }^{a}$ ND, Not determined.

correct, they represent the highest $\mathrm{G}+\mathrm{C}$ contents yet reported for any member of the Mycoplasmatales.

To determine the extent of sequence homology between the organisms, DNA-DNA hybridization values were obtained by using a variation of the methods of Denhart (2) and Gillespie and Spiegelman (6) and cellulose nitrate filters. Radioactive probes were prepared by nick translation (12); approximately $0.5 \mu \mathrm{g}$ of cold DNA was denatured by exposure to $\mathrm{NaOH}$, neutralized, and applied as a dot to filters (type HAWP; Millipore Corp.). The filters were baked at $80^{\circ} \mathrm{C}$ for $2 \mathrm{~h}$ and were presaturated with denatured salmon sperm DNA, which resulted in very low, nonspecific binding of radioactivity. Procaryotic DNA does not hybridize with eucaryotic DNA so the salmon DNA did not compete specifically. Hybridization was carried out by using an approximately 10 -fold excess of unlabeled DNA in $5.6 \times$ SSPE $(1 \times \mathrm{SSPE}$ is $0.15 \mathrm{M} \mathrm{NaCl}, 10 \mathrm{mM}$ sodium phosphate, $1 \mathrm{mM}$ EDTA [adjusted to $\mathrm{pH}$ 7.4]) supplemented with denatured salmon sperm DNA $(200 \mu \mathrm{g} / \mathrm{ml})$ and Denhart solution (2) at $65^{\circ} \mathrm{C}$ for $24 \mathrm{~h}$. Membranes were washed in $2 \times$ SSPE containing $0.1 \%$ sodium dodecyl sulfate at $45^{\circ} \mathrm{C}$ before the radioactivity on the filters was counted. These conditions approximated those recommended by Meinkoth and Wahl (9). The results of this experiment are shown in Table 2. Little binding ( 1 to $3 \%$, or slightly above the background level) occurred with either $M$. hyopneumoniae or $M$. flocculare to $M$. hominis or to $M$. pneumoniae. $M$. hyopneumoniae and $M$. flocculare showed about 10 to $11 \%$ heterologous binding, compared with homologous levels. Although there are several other newer methods for determining hybridization values, for special situations, such as the low levels of hybridization which we found, the filter membrane method remains a satisfactory and welldocumented technique.

Our results support the current classification of the four mycoplasmas that we examined as different Mycoplasma species; intraspecies hybridization values are normally more than $60 \%$ (17). Our values do suggest that the two porcinederived strains are more closely related to each other than to either $M$. hominis or $M$. pneumoniae, which were chosen as unrelated species. The hybridization values with these latter

TABLE 2. DNA-DNA hybridization values

\begin{tabular}{|c|c|c|c|c|}
\hline \multirow{2}{*}{$\begin{array}{l}\text { Radioactive probe } \\
\text { DNA }\end{array}$} & \multicolumn{4}{|c|}{$\begin{array}{c}\% \text { Hybridization with the following immobilized } \\
\text { DNA sources: }\end{array}$} \\
\hline & $\begin{array}{l}\text { M. hyopneu- } \\
\text { moniae }\end{array}$ & $\begin{array}{c}M \\
\text { flocculare }\end{array}$ & $\begin{array}{c}M . \\
\text { hominis }\end{array}$ & $\begin{array}{c}M . \\
\text { pneumoniae }\end{array}$ \\
\hline M. hyopneumoniae & $(100)^{a}$ & 11.5 & 2.8 & 2.6 \\
\hline M. flocculare & 9.7 & $(100)$ & 1.5 & 1.3 \\
\hline
\end{tabular}

${ }^{a}$ Homologous binding values were taken as $100 \%$. two species were the values expected for mycoplasmas belonging to different or unrelated species (7). Genes for transfer ribonucleic acid and ribosomal ribonucleic acid are closely conserved among mycoplasmas and, indeed, among all procaryotes (one of us [K.L.R., unpublished data] showed that an Escherichia coli $16 \mathrm{~S}$ ribosomal ribonucleic acid probe bound to an $E c o$ RI fragment of $M$. flocculare DNA, again emphasizing the conservation of these genes). Thus, a portion of all of the heterologous hybridization values are probably accounted for by complexes with these genetic sequences.

Although we studied only one strain of each of the two porcine mycoplasmas, these strains are representative of their species; we used $M$. hyopneumoniae strain 11 , which shows close antigenic cross-reactivity with at least four of seven other strains of $M$. hyopneumoniae, including type strain $\mathrm{J}(13,15)$. $M$. flocculare strain Ms42 is the type strain and the most studied strain of this species. Both organisms grew well in the medium which we used. Additional strains will be examined to determine whether the patterns described above are maintained. These studies should help to establish the relationship between the two porcine mycoplasmas and provide some explanation for the antigenic cross-reactivity between them. Because of the low percentage of heterologous binding, it was not feasible to determine the melting point for hybrid binding and, therefore, not possible to estimate the extent of sequence homologies. However, heterologous binding requires a high degree of sequence homology for at least those pieces which do bind. This, in turn, could translate to proteins and peptides with adequate amino acid sequence homologies to yield significant antigenic cross-reactivity (9).

(A portion of this work was presented at the Fifth International Congress of the International Organization for Mycoplasmology, Jerusalem, 1984.)

We gratefully acknowledge financial support by the Agricultural Research Council of Alberta (Farming for the Future grants 82-0128 and 83-0013) and by operating grant 7759 from the Medical Research Council, Ottawa, Canada.

\section{LITERATURE CITED}

1. DeLey, J. 1970. Re-examination of the association between melting point, buoyant density, and chemical composition of deoxyribonucleic acid. J. Bacteriol. 101:734-738.

2. Denhart, D. T. 1966. A membrane-filter technique for the detection of complementary DNA. Biochem. Biophys. Res. Commun. 23:641-643.

3. Freeman, M. J., C. H. Armstrong, L. L. Sands-Freeman, and M. Lopez-Osuna. 1984. Serological cross-reactivity of porcine reference antisera to Mycoplasma hyopneumoniae, $M$. flocculare, $M$. hyorhinis and $M$. hyosynoviae indicated by the enzymelinked immunosorbent assay, complement fixation and indirect hemagglutination tests. Can. J. Comp. Med. 48:202-207.

4. Freundt, E. A., and D. G. fi Edward. 1979. Classification and taxonomy, p. 1-41. In M. F. Barile, and S. Razin (ed.), The mycoplasmas, vol. 1. Academic Press, Inc., New York.

5. Friis, N. F. 1975. Some recommendations concerning primary isolation of Mycoplasma suipneumoniae and Mycoplasma flocculare. Nord. Veterinaermed. 27:337-339.

6. Gillespie, D., and S. Spiegelman. 1966. A quantitative assay for DNA-RNA hybrids with DNA immobilized on a membrane. J. Mol. Biol. 12:829-842.

7. Maniloff, J. 1983. Evolution of wall-less prokaryotes. Annu. Rev. Microbiol. 37:477-499.

8. Mare, C. J., and W. P. Switzer. 1965. Mycoplasma hyopneumoniae, a causative agent of virus pig pneumonia. Vet. Med. 60:841-846.

9. Meinkoth, J., and G. Wahl. 1984. Hybridization of nucleic acids 
immobilized on solid supports. Anal. Biochem. 138:267-284.

10. Neimark, H. C., and J. J. Pere. 1964. Characterization of pleuropneumonia-like organisms by deoxyribonucleic acid composition. Proc. Soc. Exp. Biol. Med. 118:517-519.

11. Owen, R. J., L. R. Hill, and S. P. Lapage. 1969. Determination of DNA base compositions from melting point profiles in dilute buffers. Biopolymers 7:503-516.

12. Rigby, P. W. J., M. Duchemann, C. Rhodes, and P. Berg. 1977. Labelling deoxyribonucleic acid to high specific activity in vitro by nick translation with DNA polymerase I. J. Mol. Biol. 113:237-251.

13. Ro, L. H., and R. F. Ross. 1983. Comparison of Mycoplasma hyopneumoniae strains by serological methods. Am. J. Vet. Res. 44:2087-2094.

14. Robertson, J. A. 1978. Bromthymol blue broth: improved medium for detection of Ureaplasma urealyticum (T-strain mycoplasma). J. Clin. Microbiol. 7:127-132.

15. Rose, D. L., J. G. Tully, and R. G. Wittler. 1979. Taxonomy of some swine mycoplasmas: Mycoplasma suipneumoniae Goodwin et al. 1965, a later, objective synonym of Mycoplasma hyopneumoniae Mare and Switzer 1965; and the status of Mycoplasma flocculare Meyling and Friis 1972. Int. J. Syst. Bacteriol. 29:83-91.

16. Ross, R. F. 1982. Mycoplasmal diseases, p. 535-549. In A. D. Leman, R. D. Glock, W. L. Mengeling, R. H. C. Penny, E. Scholl, and B. Straw (ed.), Diseases of swine, 5th ed. Iowa State Press, Ames.

17. Schleifer, K. H., and E. Stackebrandt. 1983. Molecular systematics of prokaryotes. Annu. Rev. Microbiol. 37:143-187.

18. Szybalski, W., and E. H. Szybalski. 1971. Equilibrium density gradient centrifugation, p. 311-354. In G. L. Contoni and D. R. Davies (ed.), Procedures in nucleic acid research, vol. 2. Harper \& Row, Publishers, New York.

19. Tully, J. G., R. F. Whitcomb, H. F. Clark, and D. L. Williamson. 1977. Pathogenic mycoplasma: cultivation and vertebrate pathogenicity of a new spiroplasma. Science 195:892-894. 